Article

\title{
Comprehensive Aging Analysis of Volumetric Constrained Lithium-Ion Pouch Cells with High Concentration Silicon-Alloy Anodes
}

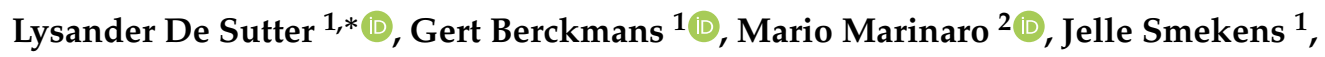 \\ Yousef Firouz ${ }^{1}$, Margret Wohlfahrt-Mehrens ${ }^{2}$, Joeri van Mierlo ${ }^{1}$ and Noshin Omar ${ }^{1}$ \\ 1 ETEC Department \& MOBI Research Group, Vrije Universiteit Brussel (VUB), Pleinlaan 2, 1050 Brussel, \\ Belgium-VUB-MOBI is a Core Lab Member of Flanders Make; Gert.Berckmans@vub.be (G.B.); \\ smekensjelle@gmail.com (J.S.); yousef.firouz@vub.be (Y.F.); Joeri.van.mierlo@vub.be (J.v.M.); \\ Noshin.omar@vub.be (N.O.) \\ 2 ZSW, Zentrum für Sonnenenergie- und Wasserstoff-Forschung BW, Helmholtzstraße 8, 89081 Ulm, \\ Germany; mario.marinaro@zsw-bw.de (M.M.); margret.wohlfahrt-mehrens@zsw-bw.de (M.W.-M.) \\ * Correspondence: lysander.de.sutter@vub.be
}

Received: 28 September 2018; Accepted: 25 October 2018; Published: 29 October 2018

\begin{abstract}
In this research, twenty-four high capacity (1360 mAh) NMC622/Si-alloy Li-ion full pouch cells with high silicon-alloy content (55\%) are cycle aged under seven different cycling conditions to study the effect of different stressors on the cycle life of Si-anode full cells, among which are the effect of ambient temperature, Depth of Discharge (DoD) and the discharge current. The cells are volumetrically constrained at an optimal initial pressure to improve their cycle life, energy and power capabilities. Furthermore, the innovative test setup allows measuring the developed pressure as a result of repeated (de-)lithiation during battery cycling. This uniquely vast testing campaign on Si-anode full cells allows us to study and quantify independently the influence of different stress factors on their cycle life for the first time, as well as to develop a new capacity fade model based on an observed linear relationship between capacity retention and total discharge capacity throughput.
\end{abstract}

Keywords: silicon; pressure; full cell; cycle aging; calendar aging; temperature influence; DoD influence; C-rate influence

\section{Introduction}

The continuous rise of long-lived greenhouse gases in our Earth's atmosphere, among which are $\mathrm{CO}_{2}, \mathrm{CH}_{4}$ and $\mathrm{N}_{2} \mathrm{O}$, presents the largest driving force behind climate change and has driven humankind to explore new technologies. Naturally, decarbonization of transportation has become a huge element of these new technologies due to the overwhelming contribution that combustion of fossil fuels presents to these harmful gases [1]. Electric Vehicles (EV), powered by rechargeable batteries rather than traditional combustion engines, show great potential in advancing this decarbonization. However, the commercial Li-ion batteries currently powering EV's are reaching their theoretical capacity limits, leaving limited opportunity to increase energy density using traditional materials [2]. Silicon (Si) presents an attractive alternative to the graphite anode material currently used in conventional Li-ion batteries owing to its natural abundance, significantly higher volumetric capacity and specific capacity $\left(2194 \mathrm{Ah} / 1\right.$ vs. $719 \mathrm{Ah} / 1$ for $\mathrm{Li}_{15} \mathrm{Si}_{4}$ and $\mathrm{LiC}_{6} ; 3579 \mathrm{mAh} / \mathrm{g}$ vs. $372 \mathrm{mAh} / \mathrm{g}$ for $\mathrm{Si}$ and graphite) $[3,4]$. However, $\mathrm{Si}$ anodes have shown poor cyclability as a result of substantial volumetric expansion/contraction (280-400\%) [3,5-14] due to repeated (de-)lithiation, giving rise to high internal stresses within the anode. Plenty of research [5-13,15-17] is available in the literature, identifying the aging mechanisms induced by electrochemical cycling of Si anode half-cells 
as: (1) deterioration of the electrode's structural integrity due to pulverization; (2) disconnection between the current collector and electrode due to (de-)lithiation-induced stress; (3) consumption of cyclable lithium in the reformation process of the damaged Solid Electrolyte Interface (SEI). However, as Dupré et al. [18] and Delpuech et al. [19] recently indicated, the aging mechanisms for full Li-ion cells with $\mathrm{Si}$ anodes appears to be different from those known for half-cells. Both research works conclude that the main aging mechanism in Si anode full cells is due to the consumption of limited available cyclable lithium by parasitic, electrolyte-additive-consuming reactions occurring well before the deterioration of electrode integrity or disconnection between active materials, as is the case for half cells. This makes a strong case for additional research focused on the aging of full Li-ion cells with $\mathrm{Si}$ anodes. Nevertheless, very few research works have been reported in the literature handling full Li-ion cells with $\mathrm{Si}$ anodes, of which an overview is presented in Table 1. Clearly, the most studied cell types are low capacity coin cells with NMC532 cathodes and anodes with low Si content $(<30 \%)$. While only Louli et al. [3] reported a study on low capacity $(<260 \mathrm{mAh})$ Si-anode pouch cells, only Chevrier et al. [20] reported on a high capacity (2 Ah) cylindrical cell with an excellent cycle life $(80 \%$ capacity retention at 500 cycles) thanks to prelithiation. Furthermore, they stand alone in employing NMC622 as the cathode material in high capacity (2 Ah) coin/cylindrical cells.

In this research, twenty-four high capacity (1360 mAh) NMC622/Si-alloy Li-ion full pouch cells with high silicon-alloy content (55\%) are cycle aged under seven different cycling conditions, including the Worldwide harmonized Light Vehicles Test Procedure (WLTP) driving cycle, to study the effect of different stressors on the cycle life of Si-anode full cells, among which are the effect of ambient temperature, Depth of Discharge (DoD) and the discharge current. Furthermore, the cells are volumetrically constrained at an optimal initial pressure to improve their energy and power capabilities, as reported in our previous work [21]. This uniquely vast testing campaign on Si-anode full cells allows for the first time to study and quantify independently the influence of different stress factors on their cycle life, as well as to develop a new capacity fade model based on an observed linear relationship between capacity retention and total discharge capacity throughput.

Table 1. Overview of available literature reporting on full $\mathrm{Li}$-ion cells with $\mathrm{Si}$ anodes and their specifications.

\begin{tabular}{|c|c|c|c|c|c|c|c|}
\hline Paper & Cell type & Cathode & Anode & Si Content & Capacity Retention & Capacity & Prelithiated \\
\hline Kierzek [22] & Coin & NMC532 & $\mathrm{Si}-\mathrm{C}$ & $18 \%$ & $72 \%$ at 100 cycles & $50 \mathrm{mAh}$ & no \\
\hline $\mathrm{Lu}[23]$ & Coin & NMC532-LFO & & & & & \\
\hline Kalaga [24] & Coin & NMC532 & Si-Gr & $15 \%$ & $66 \%$ at 100 cycles & a & no \\
\hline \multirow[t]{3}{*}{ Chevrier [20] } & Coin & NMC622 & Si-alloy & $55 \%$ & $80 \%$ at 500 cycles & $2 \mathrm{Ah}$ & yes \\
\hline & Coin & NMC622 & Si-alloy & $55 \%$ & $80 \%$ at 150 cycles & $2 \mathrm{Ah}$ & no \\
\hline & Cylindrical & NMC622 & Si-alloy & $30 \%$ & $80 \%$ at 500 cycles & $2 \mathrm{Ah}$ & yes \\
\hline Klett [25] & Coin & NMC532 & $\mathrm{Si}-\mathrm{Gr}$ & $15 \%$ & $80 \%$ at 20 cycles $^{b}$ & a & no \\
\hline Delpuech [19] & Coin & $\mathrm{LCO}$ & $\mathrm{Si}$ & a & $80 \%$ at 20 cycles $^{b}$ & a & no \\
\hline Dupré [18] & Coin & NMC111 & $\mathrm{Si}-\mathrm{C}$ & $80 \%$ & $80 \%$ at 20 cycles $^{b}$ & a & no \\
\hline \multirow[t]{3}{*}{ Louli [3] } & Pouch & NCA & $\mathrm{SiO}-\mathrm{Gr}$ & a & a & $260 \mathrm{mAh}$ & no \\
\hline & Pouch & $\mathrm{LCO}$ & Si-Alloy & a & $86 \%$ at 90 cycles & $230 \mathrm{mAh}$ & no \\
\hline & Pouch & NCA & Si-C & a & $93 \%$ at 90 cycles & $165 \mathrm{mAh}$ & no \\
\hline Marinaro [26] & Pouch & NMC532 & Si-alloy & $55 \%$ & $80 \%$ at 290 cycles & $1.22 \mathrm{Ah}$ & no \\
\hline Gabrielli [27] & Coin & LMNO-O/R & $\mathrm{Si}-\mathrm{C}$ & $75 \%$ & $75 \%$ at 100 cycles & a & no \\
\hline
\end{tabular}

${ }^{\mathrm{a}}$ Information unavailable in publication; ${ }^{\mathrm{b}}$ Not explicitly mentioned, deduced from publication information.

The paper is structured as follows: Section 2 presents the characteristics of the investigated Si-alloy cells and their imposed volumetric constraints. Section 3 presents the lifetime testing methodology followed throughout this research, including testing procedures and the selection of cycling conditions. Section 4 introduces the results of the lifetime study and discusses them in depth. Section 5 presents the observed relationship between capacity retention and total capacity throughput, followed by a methodology to implement the relation for capacity fade modeling. Finally, Section 6 presents the conclusions and future work. 


\section{Silicon Li-Ion Batteries}

\subsection{Investigated Cells}

The investigated next-generation cells in this research are full pouch cells built from prototype materials, assembled by the Zentrum für Sonnenenergie und Wasserstoff-Forschung (ZSW) with an NMC622 cathode developed by Umicore and adjusted binders developed by Arkema. The anode consists of $55 \%$ Si-alloy, developed by $3 \mathrm{M}$, combined with graphite. The electrolyte is composed of $1 \mathrm{M} \mathrm{LiPF}_{6}$ and $0.1 \mathrm{M}$ Lifetime Electrolyte Arkema (LEA) in EC:EMC3:7 (V/V) combined with $10 \%$ Fluoroethylene Carbonate (FEC). This cell is the third generation of cells developed during the European FiveVB project (www.fivevb.eu), funded by the Horizon 2020 research and innovation program of the European Commission. These next generation electrode materials result in a voltage window of $2.7 \mathrm{~V}-4.4 \mathrm{~V}$, a nominal capacity of $1360 \mathrm{mAh}$ (average measurement during first $\mathrm{C} / 25$ discharge for 33 tested cells) and a specific energy of $205 \mathrm{Wh} / \mathrm{kg}$. A summary of the tested Si-alloy cell specifications is presented in Table 2 .

Table 2. Cell specifications of tested 1360-mAh NMC622/Si-alloy pouch cells.

\begin{tabular}{|c|c|}
\hline Properties & Value \\
\hline \multicolumn{2}{|c|}{ Cathode Composition } \\
\hline$\overline{L i N i_{0.6} \mathrm{Mn}_{0.2} \mathrm{Co}_{0.2} \mathrm{O}_{2}}$ & $93 \%$ \\
\hline Carbon & $4 \%$ \\
\hline HSV1800 (Arkema) & $3 \%$ \\
\hline Loading $\left(\mathrm{mg} / \mathrm{cm}^{2}\right)$ & 17.5 \\
\hline Electrode density (g/cc) & 3.0 \\
\hline \multicolumn{2}{|c|}{ Anode Composition } \\
\hline Si-alloy (3M) & $55 \%$ \\
\hline SMG-A3 & $33 \%$ \\
\hline LiPAA & $10 \%$ \\
\hline Super-PLi & $2 \%$ \\
\hline Loading $\left(\mathrm{mg} / \mathrm{cm}^{2}\right)$ & 6.5 \\
\hline Electrode density (g/cc) & 1.7 \\
\hline \multicolumn{2}{|l|}{ Electrical } \\
\hline Nominal capacity (mAh) & 1360 \\
\hline Upper cut-off voltage (V) & 4.4 \\
\hline Lower cut-off voltage (V) & 2.7 \\
\hline Specific energy (Wh/kg) & 205 \\
\hline
\end{tabular}

\subsection{Electrical Characterization}

To establish the baseline electrical performance of the Si-alloy cells, as well as to evaluate their electrical performance over their lifetime, three well-defined characterization tests are performed: a capacity test, a Quasi-Open Circuit Voltage test (QOCV) and a Hybrid Pulse Power Characterization test (HPPC). The standardized capacity test [28-31] is utilized to evaluate the cell's discharge capacity at various c-rates by using constant current constant voltage charging cycles followed by a constant current discharge at $0.1 \mathrm{C}, 0.2 \mathrm{C}, 0.33 \mathrm{C}, 1 \mathrm{C}$ and $1.5 \mathrm{C}$. The Beginning of Life (BoL) capacity test results for all tested cells in this research are summarized in Figure 1a. The median capacity values are 1347.7 mAh, $1329.5 \mathrm{mAh}, 1310.6 \mathrm{mAh}, 1255.9 \mathrm{mAh}$ and $1215.6 \mathrm{mAh}$ for $0.1 \mathrm{C}, 0.2 \mathrm{C}, 0.33 \mathrm{C}, 1 \mathrm{C}$ and $1.5 \mathrm{C}$, respectively. Furthermore, the maximum deviation from the median capacity never exceeds $2.5 \%$ over all c-rates, which testifies to a high quality manufacturing process performed by ZSW.

The QOCV test is used as a time efficient non-standardized test to approximate the open circuit voltage of a cell over the State of Charge (SoC), by charging and discharging the cell at a very low constant current of $C / 25$, as can be seen in Figure $1 \mathrm{~b}$. Furthermore, this test is utilized as a check-up test to assess capacity degradation during cycle aging, which is further explained in Section 3.2. 
Finally, the HPPC test is employed to evaluate the electrical and dynamic behavior of the cell over the entire $\mathrm{SoC}$ window. This is achieved by imposing a train of alternating charge and discharge current pulses at $0.2 \mathrm{C}, 0.33 \mathrm{C}, 1 \mathrm{C}, 1.5 \mathrm{C}$ and $2 \mathrm{C}$ at every $5 \% \mathrm{SoC}$ interval. Analyzing the measured voltage response from this test offers a range of possibilities to evaluate the cell's behavior, e.g., electrical modeling, assessing battery internal resistance and assessing power capabilities.
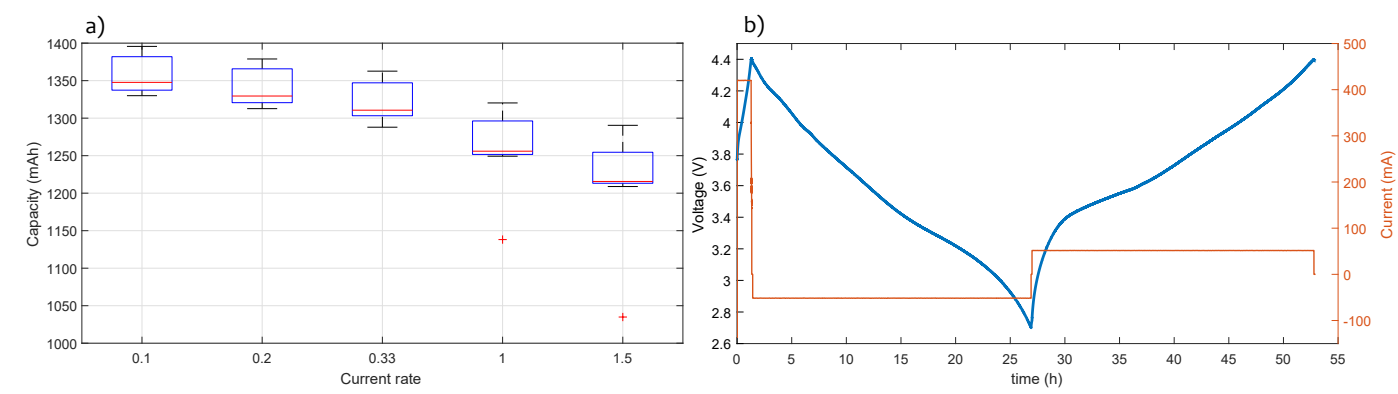

Figure 1. (a) Statistical analysis on the discharge capacity of Silicon cells at Beginning of Life (BoL) and (b) quasi-open circuit voltage test performed at BoL on a silicon cell.

\subsection{The Influence of Pressure}

It is widely reported in the literature that silicon anodes endure substantial volumetric expansion/contraction (280-400\%) due to repeated (de-)lithiation, giving rise to high internal stresses within the anode, which lead to continuous repair of the damaged SEI and ultimately result in the consumption of cyclable lithium and capacity fade [3,5-14]. In an initial effort to monitor this characteristic behavior, it was observed that applying external pressure perpendicular to the cell's electrodes by constraining it volumetrically improved both its energy and power capabilities, as reported in our previous work [21]. In order to study the influence of the applied external pressure on the Si-alloy pouch cell's cycle life and identify the optimal initial pressure, a dedicated setup was developed as shown in Figure 2. The Si-alloy cells are volumetrically constrained on a 3D-printed battery holder, with built-in electrical connectors, by an aluminum pressure plate. A Tekscan ${ }^{\mathrm{TM}}$ Flexiforce resistive pressure sensor is mounted between the lower pressure plate and a second, upper pressure plate. Thanks to this innovative setup, tightening of four screws allows to regulate the applied initial pressure on the Si-alloy cell during the calibration procedure, while the pressure sensor allows measuring the perpendicular counterforce as a result of repeated (de-)lithiation during battery cycling. In the performed pressure study, four Si-alloy cells were cycle aged with different starting pressures to study the effect on their respective capacity retention and identify the optimal initial pressure for maximal cycle life. The pressure study results are presented in Section 4.1.

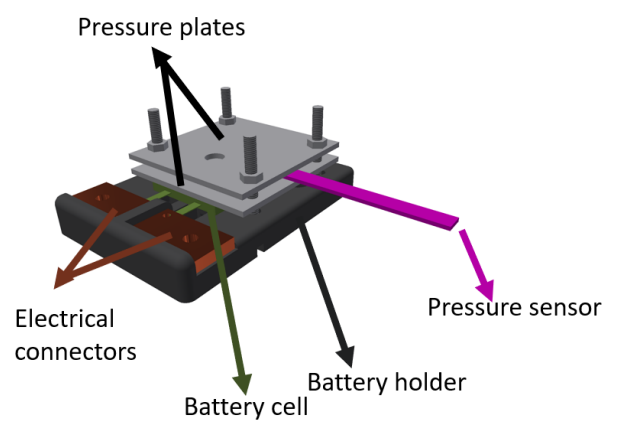

Figure 2. Pressure setup to monitor developed perpendicular counterforce due to repeated (de-)lithiation of the Si-alloy full cells [21]. 


\section{Lifetime Testing Methodology}

\subsection{Capacity Fade Model Concept}

The aging of Li-ion batteries can be divided into two separate mechanisms: cycle aging and calendar aging, where cycle aging is the degradation that occurs due to repeated (dis-)charging of the cell and calendar aging is the degradation attributed to storing the cell at curtain storage conditions. Due to limited cell availability, it was preferred to consider the effects of cycle aging exclusively for the capacity fade model. Nevertheless, calendar aging was also performed on a small amount of cells. To develop a comprehensive understanding of the Si-alloy full cell's cycle aging and degradation mechanisms under different operational conditions, the essential stress factors, which greatly influence the cycle aging, are identified to be: current rate, temperature and DoD [32-36]. Figure 3 presents a flowchart overview of the methodology followed during this research. After the identification of the optimal initial pressure during the pressure study (Section 2.3), the influence of current rate, depth of discharge and ambient temperature on the cycle life of the Si-alloy cells is studied independently (Section 3.2). This allows creating a semi-empirical capacity fade model and reveals the influence that the identified stress factors have on the aging mechanisms of the full cell Li-ion batteries with Si-alloy anodes for the first time.

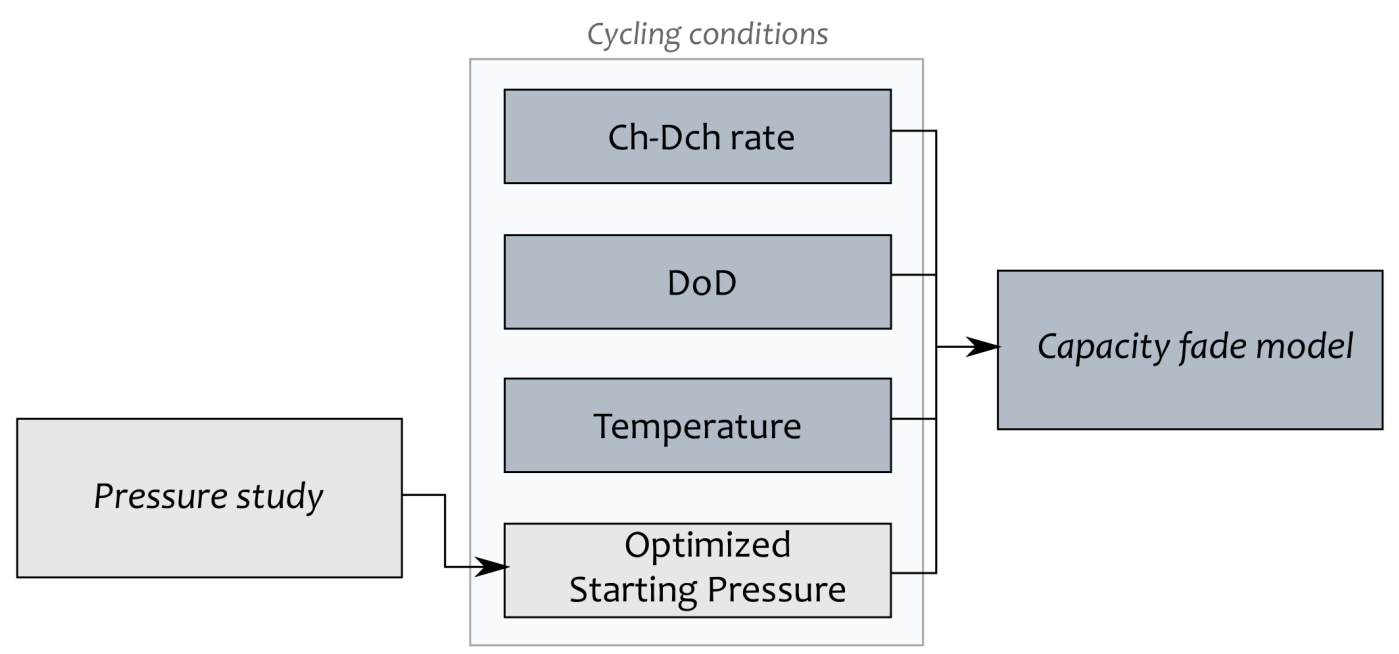

Figure 3. Overview of the performed lifetime study and developed capacity fade model of silicon cells.

\subsection{Testing Procedure}

In order to obtain the necessary empirical data to study the aging phenomena of the Si-alloy full cells under various conditions and create the capacity fade model, a meticulous testing procedure was conceived of and strictly followed throughout every cycling condition, which is shown in Figure 4. A fresh cell first undergoes BoL characterization, which consists of three conventional electrical characterization tests for Li-ion batteries: a capacity test, a QOCV test and an HPPC test (Section 2.2). After the BoL characterization is completed, 50 cycles are performed at the given cycling condition. Hereafter, a short check-up is performed, which consists solely of a QOCV test to minimize additional aging due to characterization tests. After 50 more cycles at the given cycling condition, a detailed check-up is performed, which consists of the same electrical characterization tests as the BoL characterization. This procedure is repeated until the cell reaches End of Life (EoL), which is defined in this research as $80 \%$ capacity retention. 


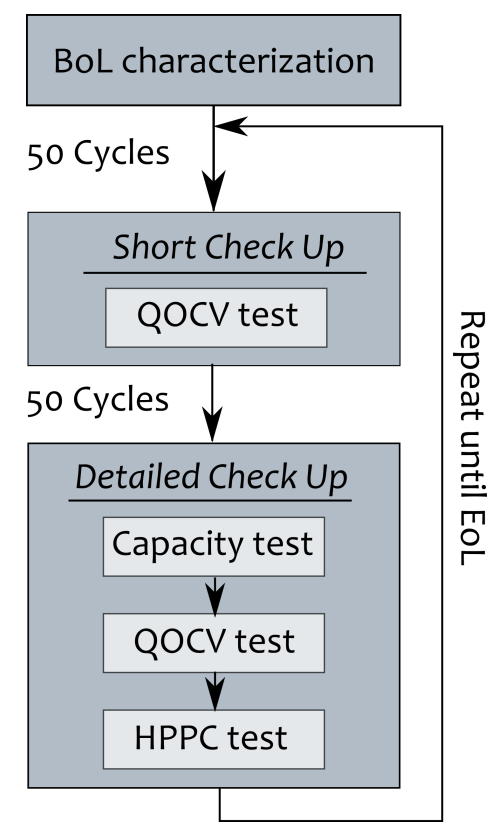

Figure 4. Flowchart representation of the testing procedure for lifetime testing of Si-alloy full cells.

\subsection{Cycle Aging Test Campaign}

To investigate the influence of the identified stress factors on battery lifetime independently, the test campaign shown in Table 3 was developed. Eighteen prototype, next generation, NMC622/Si-alloy cells are cycled under seven different cycling conditions. To demonstrate the repeatability of the results, every cycling condition is tested twice. All cells are cycled at the identified optimal initial pressure of $7.5 \mathrm{~kg}$ (Sections 2.3 and 4.1). To the author's best knowledge, no previous research exists that investigates the cycle aging of such a vast amount of Si-alloy anode full cells under different cycling conditions, nor volumetrically constraining the cell during cycling.

The cycling conditions shown in Table 3 are considered to be constant current cycles. All these tests share the same foundation as they commence with a constant current charge at $C / 3$ followed by a constant voltage charge at $4.4 \mathrm{~V}$ to ensure the cell is fully charged before cycling. Hereafter, 50 full charge and discharge cycles are performed, after which the cell is charged back to $3.7 \mathrm{~V}$ for safe storage. The specificity of each cycling condition lies with the current rate at which the charge and discharge cycles are performed, how deep the cell is discharged and the ambient temperature of the climate chamber. The current rate was varied between $\mathrm{C} / 3$ and $1 \mathrm{C}$; the temperature was varied between $10{ }^{\circ} \mathrm{C}, 25^{\circ} \mathrm{C}$ and $45{ }^{\circ} \mathrm{C}$; while the DoD was $60 \%, 80 \%$ or $100 \%$. It should be noted that DoD is defined in this research with reference to $50 \%$ middle SoC, meaning that $60 \%$ DoD cycles between $80 \%$ and $20 \%$ SoC, $80 \%$ DoD cycles between $90 \%$ and $10 \%$ SoC and $100 \%$ DoD operates between $100 \%$ and $0 \%$ $(4.4 \mathrm{~V}-2.7 \mathrm{~V})$ SoC.

In an effort to extend the understanding of the Si-alloy battery lifetime to more practical automotive applications, a real-life driving cycle test condition was developed, based on the WLTP. The standardized speed profile was converted to a load current expressed in C-rate. Two validation cells are cycle aged at $25^{\circ} \mathrm{C}$ by performing ten consecutive WLTP cycles after a constant current charge at $\mathrm{C} / 3$. This process is repeated fifty times before the cell's remaining performance is evaluated during a detailed check-up. Besides offering compelling insights towards the real-life applicability of Si-alloy Li-ion cells, this test condition also serves as the dynamic validation profile for the developed capacity fade model. 
Table 3. Cycle aging test campaign.

\begin{tabular}{ccccc}
\hline \multicolumn{2}{c}{ DoD } & $\mathbf{1 0 0 \%}$ & $\mathbf{8 0 \%}$ & $\mathbf{6 0 \%}$ \\
\hline $\mathrm{T}$ & $\mathrm{C}-$ rate & & & \\
$10{ }^{\circ} \mathrm{C}$ & $\mathrm{C} / 3$ & 2 & & \\
$25{ }^{\circ} \mathrm{C}$ & $\mathrm{C} / 3$ & 2 & 2 & 2 \\
$45^{\circ} \mathrm{C}$ & $\mathrm{C} / 3$ & 2 & & \\
\hline
\end{tabular}

\section{Results and Discussion}

\subsection{Pressure Study}

To investigate the influence of the initial applied pressure on the cycle life of Si-alloy cells, an extensive pressure study was performed prior to the actual cycle aging campaign. Eight cells were cycle aged under identical conditions (c-rate, DoD and temperature), but the initial perpendicular pressure applied on the cell's surface was randomly varied between $3.25 \mathrm{~kg}, 7.5 \mathrm{~kg}, 11.25 \mathrm{~kg}$ and $15 \mathrm{~kg}$. Hereafter, the cells were cycled at the benchmark cycling condition of $\mathrm{C} / 3$ charge and discharge current, $100 \%$ DoD and at an ambient temperature of $25^{\circ} \mathrm{C}$, according to the aforementioned testing procedure (Section 3.2). For repeatability, each initial pressure was tested on two cells. The average measured capacity retention over the battery lifetime during the QOCV check-up tests is presented for all cells in Figure 5, along with their respective error bars. From the obtained results, it was concluded that applying external pressure on the Si-alloy pouch cells significantly increased battery performance, as reported in our previous work [21]. However, no clear relation was observed between the amount of pressure and the cell's capacity retention, as long as a curtain threshold pressure was met. Consequently, the optimal initial pressure for further cycle age testing was identified to be $7.5 \mathrm{~kg}$, as it showed slightly better average capacity retention (1.9\%) than the $3.5-\mathrm{kg}$ case, while increasing the pressure beyond the $7.5-\mathrm{kg}$ threshold to $11.25 \mathrm{~kg}$ and $15 \mathrm{~kg}$ led to a $3.3 \%$ and $1.0 \%$ decrease in capacity retention, respectively.

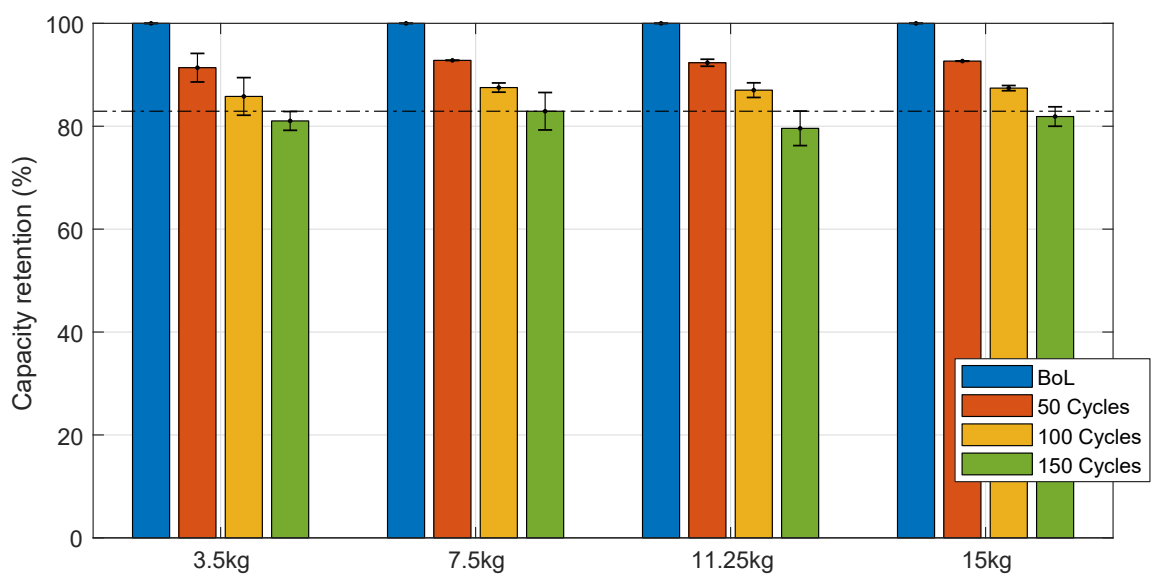

Figure 5. Influence of the initial applied perpendicular pressure on Si-alloy cell's capacity retention, where the black horizontal line indicates the optimum capacity retention after 150 cycles.

\subsection{Capacity Degradation}

\subsubsection{The Influence of Current Rate}

The influence of current rate on Si-alloy battery lifetime was examined by cycle aging four cells, two of which at a current rate of $\mathrm{C} / 3$ and two at a current rate of $1 \mathrm{C}$, while the other main identified stress factors for battery degradation, DoD and temperature were kept constant at $100 \%$ and $25^{\circ} \mathrm{C}$, respectively. The State of Health $(\mathrm{SoH})$ of each cell was determined based on the discharged capacity 
of every performed cycle relative to the discharged capacity during the second cycle, as defined by Equation (1). The discharge capacity obtained from the second cycle $\left(C_{c y c l e, 2}\right)$ was designated as the reference capacity rather than the first cycle due to the test design. As discussed in Section 3.3, every cycling block started with a constant current charge at $\mathrm{C} / 3$ followed by a constant voltage charge at $4.4 \mathrm{~V}$ to ensure the cell was fully charged. However, during the cycling block, only constant current charging was performed, leaving out the constant voltage charge, which naturally resulted in a lower discharged capacity for the consecutive cycles. Correspondingly, using the discharged capacity from the first cycle would result in an unrealistic drop of the SoH of up to $4.7 \%$ after the first cycle. It should be mentioned that the observed peaks in SoH every fifty cycles were also attributed to the CCCV charge of every new cycling block.

$$
\text { SoH }=\frac{C_{c y c l e, k}}{C_{c y c l e, 2}} \cdot 100 \%
$$

From the presented results in Figure 6, it is clear that an increased current rate has an adverse effect on battery lifetime. The average cycles to end of life diminished from 160 to 143 for a current rate of $C / 3$ and $1 C$, respectively, which corresponds to a significant decrease in battery lifetime of $10.6 \%$. Furthermore, the obtained results show excellent repeatability under both cycling conditions. The cells cycled at the higher c-rate of $1 \mathrm{C}$ showed a dissimilarity in the number of cycles to EoL of only one (144 cycles and 142 cycles), while both cells cycled at the lower c-rate of C/3 reached EoL after 159 and 160 cycles, respectively. The number of cycles reached to end of life for each cell at every cycling condition during this research is summarized in Table 4.

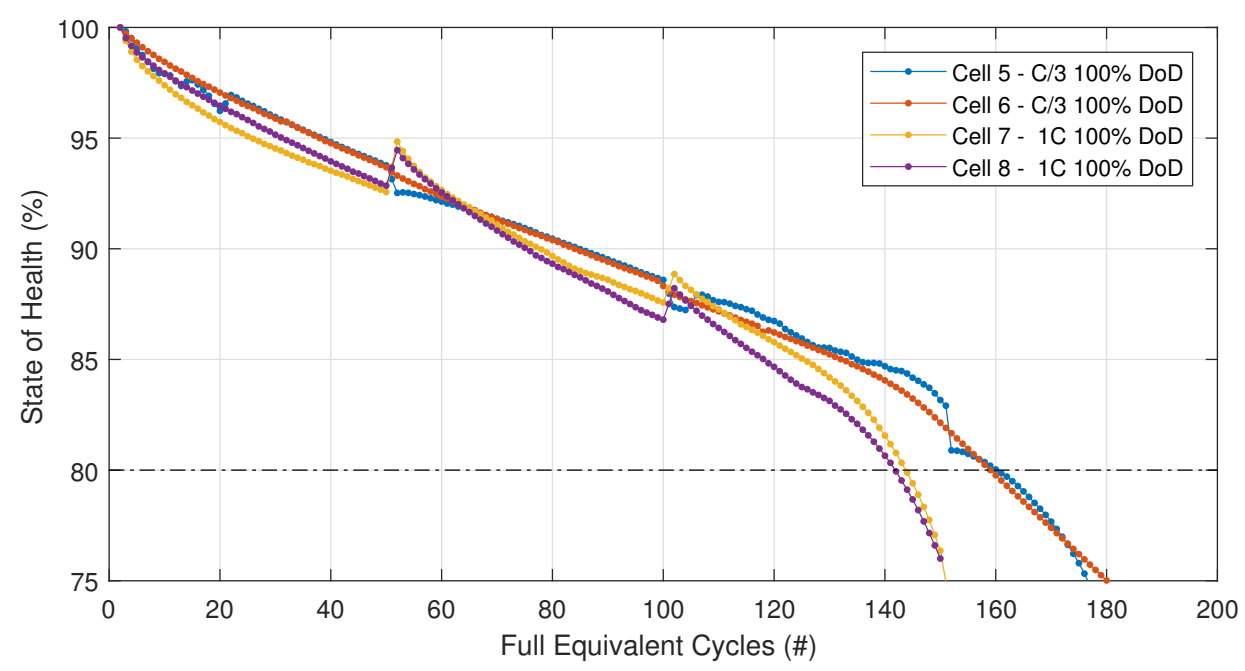

Figure 6. The influence of current rate on capacity retention over battery lifetime during cycling, where the black line indicates End of Life (EoL). Increases in SoH at Cycles 51 and 101 due to CCCV charge at the start of the cycling block, instead of consecutive $\mathrm{C} / 3$ charges.

Table 4. Number of full equivalent cycles to end of life for both tested cells at every cycling condition.

\begin{tabular}{ccccc}
\hline \multicolumn{2}{c}{ DoD } & $\mathbf{1 0 0 \%}$ & $\mathbf{8 0} \%$ & $\mathbf{6 0 \%}$ \\
\hline T & C-rate & & & \\
10 & $\mathrm{C} / 3$ & $107 / 104$ & & \\
& $\mathrm{C} / 3$ & $160 / 159$ & $161 / 159$ & $244)^{a}$ \\
25 & $1 \mathrm{C}$ & $144 / 142$ & & \\
45 & $\mathrm{C} / 3$ & $39 / 37$ & & \\
\hline \multicolumn{5}{c}{ a Cell did not reach end of life conditions. }
\end{tabular}




\subsubsection{The Influence of Depth of Discharge}

The influence of the depth of discharge on Si-alloy battery lifetime was evaluated by cycle aging six cells, of which two cells at respectively $100 \%, 80 \%$ and $60 \%$ DoD, while the other main identified stress factors for battery degradation, current rate and temperature were kept constant at $\mathrm{C} / 3$ and $25{ }^{\circ} \mathrm{C}$. Figure 7 shows the SoH over battery lifetime, calculated from the obtained discharge capacity during a QOCV check-up test, which was performed every fifty cycles. For the clarity of the presented results, only one cell at each DoD cycling condition is shown. However, the mean difference on the measured SoH was only $0.4 \%$ for all six cells with a maximum deviation of $0.6 \%$, which demonstrates the repeatability of the obtained results. Furthermore, it should be noted that cycle life is presented using full equivalent cycles, where one full equivalent cycle is defined as consuming $100 \%$ of the nominal battery capacity followed by recharging $100 \%$ of the nominal capacity, in order to allow one on one comparison between the different cycling conditions' lifetime. The results reveal a drastic improvement in cycle life for the Si-alloy cells with reduced DoD cycling conditions of up to 100 full equivalent cycles.

A reasonable explanation for this phenomenon is the continuous growth of the SEI layer on the silicon-alloy anode, owing to the induced stress of repeated (de-)lithiation of silicon particles during which gradual consumption of cyclable lithium occurs and the electrolyte additive FEC is depleted by parasitic reactions on the anode $[8,18,19,37]$. While volumetric expansion perpendicular to the electrode's surface is inhibited by the external pressure applied on the cells through the test setup, lateral volumetric expansion is only limited by intrinsic cell dimensions. However, it is proposed that the detrimental effect of the large pressure variations outweigh the small lateral volumetric changes and present the major driving force behind the cell's degradation. This posit is substantiated by pressure measurements taken on the cells during the first fifty cycles, which are presented in Figure 8a. A clear relationship between pressure variation $\Delta P$ and cycling $\mathrm{DoD}$ can be observed where cycling conditions at $100 \%, 80 \%$ and $60 \%$ DoD show a pressure variation of $3.6 \mathrm{~kg}, 3.4 \mathrm{~kg}$ and $2.2 \mathrm{~kg}$, respectively. Furthermore, Klett et al. [37] have previously reported a significant improvement (up to $10 \%$ ) in capacity retention of NMC532/Si-Gr coin cells with low silicon content (15 wt \% Si) after 100 cycles, when cycling at a more narrow voltage window. They postulated that by discharging to a lower cut-off voltage, the Si-Gr anode potential rises, which enhances the fracture of the Si particles caused by the deeper discharge and enhances SEI decomposition at high anode potentials. Comparing the total discharge throughput during cycling against the capacity retention allows assessing the likelihood that pressure variations induced by repeated (de-)lithiation influence the cell's cycle life. After all, a cell with a lower total discharge throughput is expected to have an increased capacity retention caused by a smaller pressure change due to less (de-)lithiation. Indeed, Figure $8 \mathrm{~b}$ shows that over battery lifetime (after 50, 100 and 150 cycles), cells with a lower total discharge throughput show improved capacity retention. Combined with the presented pressure measurements and improved lifetime of the $60 \%$ DoD cycling condition, this allows us to conclude that the internal pressure variations developed by volumetric constrained silicon-alloy cells had a substantial influence on their cycle life. 


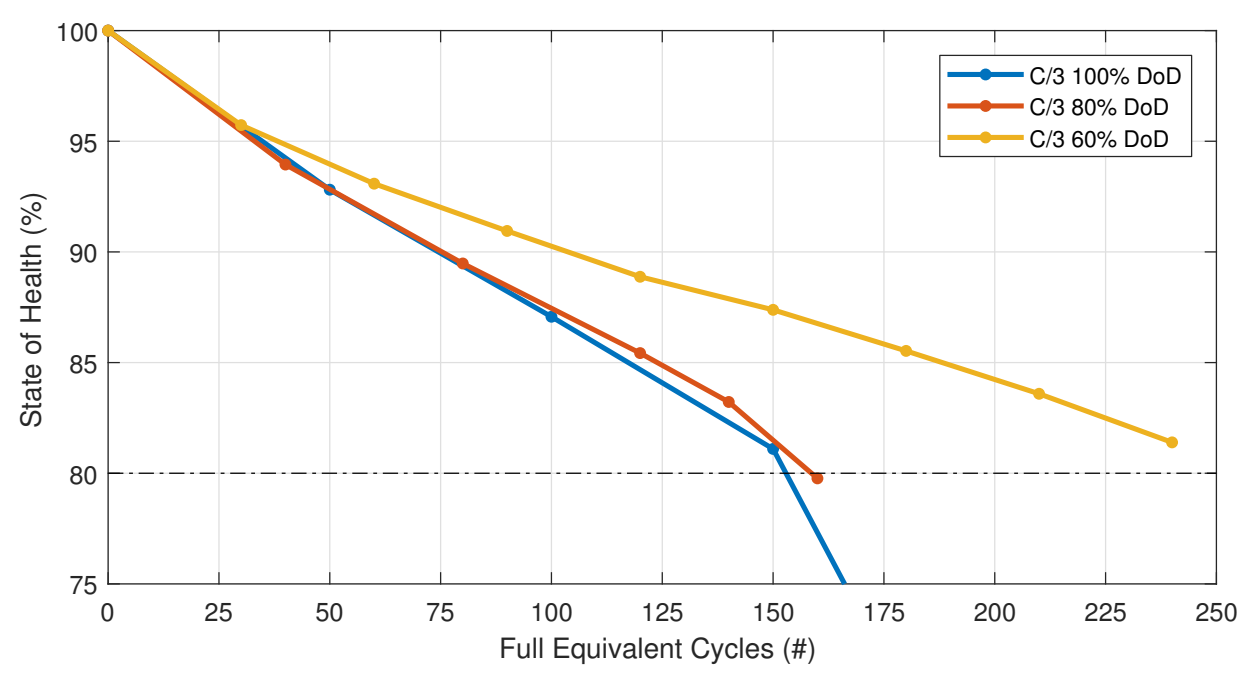

Figure 7. The influence of DoD on capacity retention over battery lifetime, where the black line indicates EoL.

a)

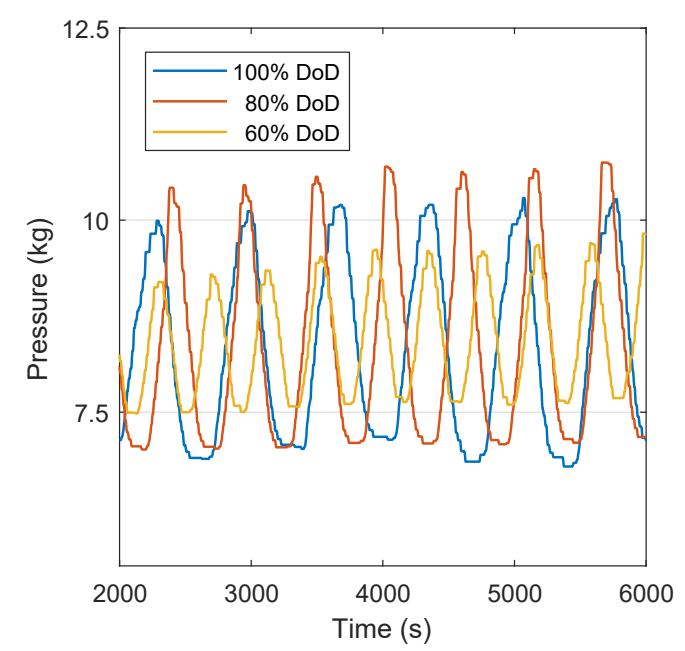

b)

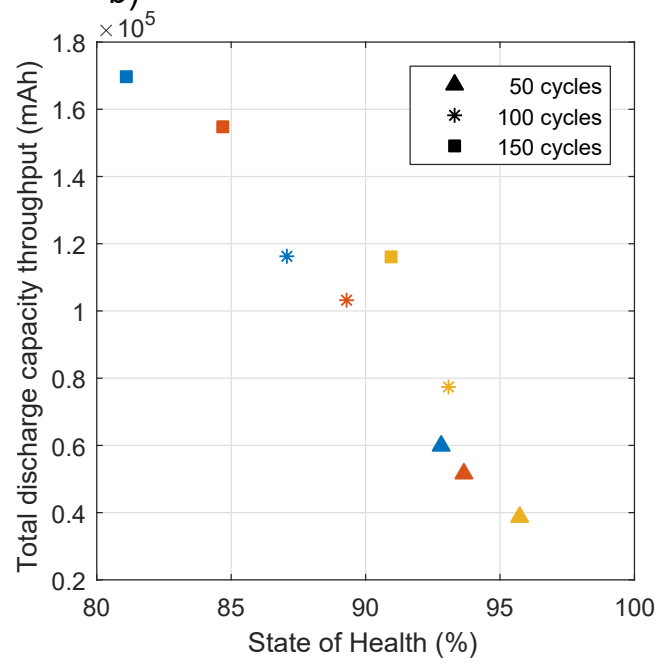

Figure 8. The effect of cycling DoD on (a) the cell's generated perpendicular counterforce pressure due to volumetric constraints and (b) total discharge capacity throughput after 50, 100 and 150 cycles; the color legend in (b) is identical to (a).

\subsubsection{The Influence of Temperature}

The influence of the ambient temperature on Si-alloy battery lifetime was evaluated by cycle aging six cells, of which two cells were at respectively $10{ }^{\circ} \mathrm{C}, 25^{\circ} \mathrm{C}$ and $45^{\circ} \mathrm{C}$, while the other main identified stress factors for battery degradation, current rate and depth of discharge were kept constant at $\mathrm{C} / 3$ and $100 \%$. From the results shown in Figure 9, a clear trend of rising aging rates was observed for both $10^{\circ} \mathrm{C}$ and $45^{\circ} \mathrm{C}$ cycling conditions. These findings are in agreement with the available literature on the aging of conventional Li-ion batteries [32-34,38-40], where it is shown that in low temperature cycling $\left(\mathrm{T}<25^{\circ} \mathrm{C}\right)$, lithium plating on the anode and successive reactions with the electrolyte caused a loss of lithium and resulting capacity fade; while at higher temperatures $\left(\mathrm{T}>25^{\circ} \mathrm{C}\right)$, other aging mechanisms were predominantly reported, such as degradation of the cathode and the growth of the SEI layer. However, to the author's best knowledge, no literature of the ambient temperature's impact on the cycle life of $\mathrm{Si}$ anode full cells is currently available. Even the effect of ambient temperature on Si half cells is barely reported. Haruta et al. studied the effect of different SEI-forming additives on the cycle 
performance of Si nanoflake powder anodes [15]. They reported an $11 \%$ decrease in capacity retention after 50 cycles between $30^{\circ} \mathrm{C}$ and $60^{\circ} \mathrm{C}$ when utilizing $10 \mathrm{wt} \%$ FEC as electrolyte additive and a substantially larger capacity loss at $-5^{\circ} \mathrm{C}$. Interestingly, the half cells containing additives showed worse capacity retention at low temperatures than those that did not. In [18], the influence of an elevated temperature $\left(55^{\circ} \mathrm{C}\right)$ compared to room temperature $\left(25^{\circ} \mathrm{C}\right)$ on the calendar aging of full cell $\mathrm{NMC111/Si} \mathrm{coin} \mathrm{cells} \mathrm{was} \mathrm{presented.} \mathrm{It} \mathrm{was} \mathrm{reported} \mathrm{that} \mathrm{the} \mathrm{parasitic,} \mathrm{electrolyte-additive-consuming}$ reactions at the anode surface occurred spontaneously and were thermally activated. To confirm this thermal activation in our Si-alloy pouch cells, as it might explain the drastic reduction in the $45^{\circ} \mathrm{C}$ cycle life observed in Figure 9, two cells were calendar aged at $4.4 \mathrm{~V}(100 \% \mathrm{SoC})$ using the same volumetric constrained pressure setup as used for the cycle aging (Section 2.3), which exerted $7.5 \mathrm{~kg}$ of initial pressure on the cells. From the obtained results, shown in Figure 10, it is confirmed that the parasitic degradation of the electrolyte at the anode took place without (de-)lithiation and was significantly thermally intensified. Furthermore, the cell calendared at $45{ }^{\circ} \mathrm{C}$ showed considerable bulging after reaching EoL, which indicates the formation of gases. It has been reported $[16,17,21]$ that the main decomposition products of fluoroethylene carbonate are $\mathrm{CO}_{2}$ and $\mathrm{LiF}$, where the formation of $\mathrm{CO}_{2}$ gas explains the cell bulging and thus confirms that the electrolyte degradation was thermally enhanced. It is thus proposed that the drastically reduced cycle life of the Si-alloy cells at $45{ }^{\circ} \mathrm{C}$ was caused by an increased reaction rate of the parasitic electrolyte degradation, which resulted in $\mathrm{CO}_{2}$ gas formation, increasing the internal pressure of the cell, which damaged the SEI layer further and thus resulted in an increased consumption rate of cyclable lithium and capacity loss.

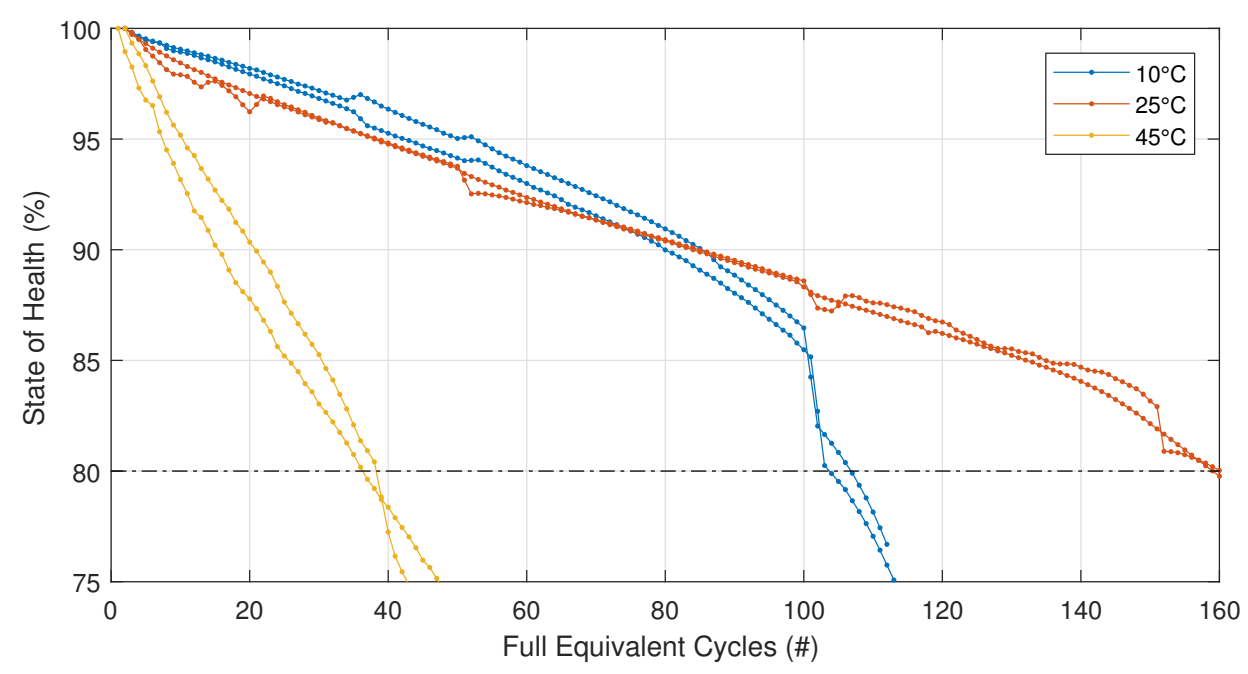

Figure 9. The influence of ambient temperature on capacity retention over Si-alloy battery lifetime, where the black line indicates EoL. 


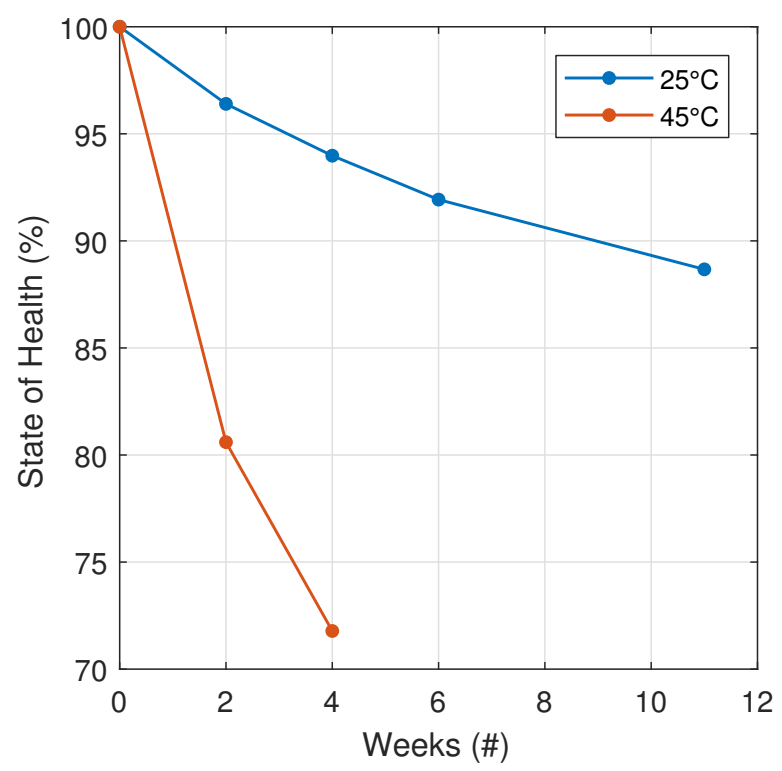

Figure 10. Discharge capacity of two calendar aged Si-alloy cells at $25^{\circ} \mathrm{C}$ and $45^{\circ} \mathrm{C}$, stored at $4.4 \mathrm{~V}$ $(100 \%$ SoC) and both stored at an optimized initial pressure of $7.5 \mathrm{~kg}$.

\subsubsection{The Influence of Real-Life Driving}

In an effort to extend the understanding of the Si-alloy battery aging to more practical automotive applications, a real-life driving cycle test condition was developed, based on the WLTP. This test condition also served as the dynamic validation profile for the developed capacity fade model presented in Section 5. As previously described in Section 3, the cells underwent ten consecutive standardized WLTP driving cycles before being recharged to $4.4 \mathrm{~V}$ (100\% SoC). This cycling block was repeated fifty times, concurring with 500 total WLTP cycles in between cell check-ups. Since one WLTP cycle corresponds to 23.3 driven kilometers, a driving distance of $233 \mathrm{~km}$ was simulated between charging events, and a total driven distance of $11,650 \mathrm{~km}$ was simulated between every check-up. Figure 11 presents the measured capacity retention during check-ups of the WLTP cycling conditions. It is observed that the Si-alloy cells showed excellent capacity retention throughout the drive cycle aging, where Cell 1 maintained $88.5 \%$ of it's initial capacity after $46,600 \mathrm{~km}(=200$ cycles $\times 10$ WLTP's $/$ cycle $\times 23.3 \mathrm{~km} / \mathrm{WLTP})$. Assuming that the aging rate remains constant from the second measurement point on, linear extrapolation of the capacity retention obtained an estimate of $98536 \mathrm{~km}$ to battery EoL. This assumption was justified by the observed strong linear relationship $\left(R^{2}=0.997\right)$ between the capacity retention and number of cycles when excluding the first measurement; while leaving out the first measurement point for the extrapolation was justified by the high initial irreversible capacity loss that occurred during the first few cycles in $\mathrm{Si}$ cells $[2,41]$. Either way, it was concluded that the studied Si-alloy cells showed promising prospects for automotive applications.

\subsection{Pressure Evolution over Battery Lifetime}

Over the past few years, only a handful of publications have dealt with the measurement and effect of stress induced by (de-)lithiation in various electrodes [3,42-48]. A few researchers have successfully used stress measurements on pouch cells of various conventional chemistries for SoC $[46,47]$ and SoH $[45,46,48]$ estimations. However, to the author's best knowledge, only one publication briefly mentions the evolution of pressure over the lifetime of pouch cells with silicon-based anodes (SiO-graphite, Si-alloy and nano-Si:carbon) [3]. As previously mentioned, pressure measurements were performed during all tests in the presented aging campaign of this research, which offer a compelling insight towards the evolution of pressure over Si-alloy battery 
lifetime. Figure 12 presents the general evolution in pressure observed during all cycling conditions: as the discharge capacity decreases, an irreversible pressure increase transpires. A clear relationship can be identified between capacity retention and the pressure behavior of our Si-alloy cells, which implies a correlation between the main aging mechanism within Si-alloy cells and their irreversible pressure growth. However, the in-depth analysis of the pressure measurements will be presented extensively in our future work.

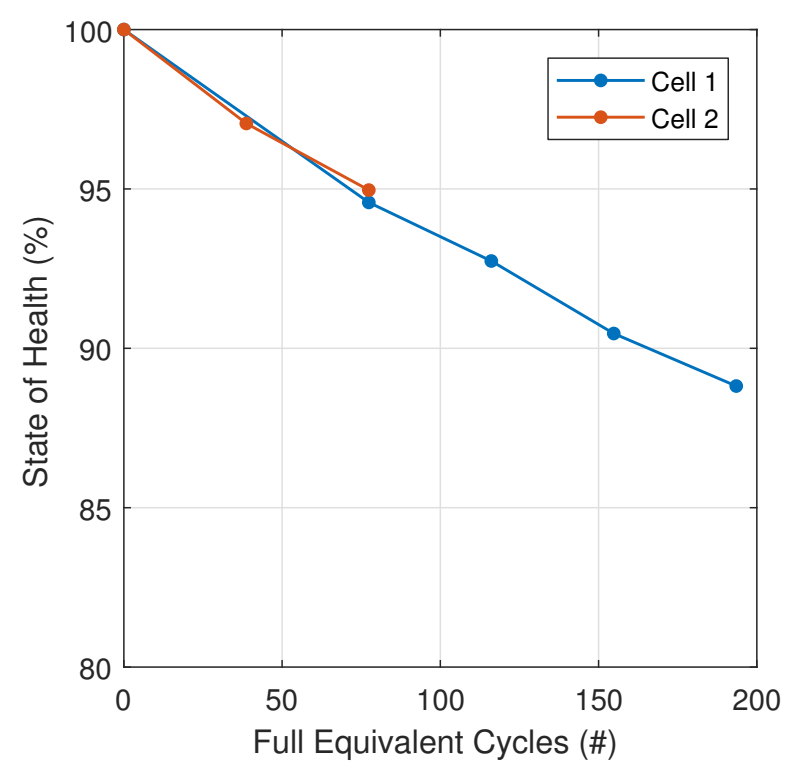

Figure 11. The influence of the standardized Worldwide harmonized Light vehicle Test Procedure (WLTP) driving cycles on the capacity retention of Si-alloy cells.

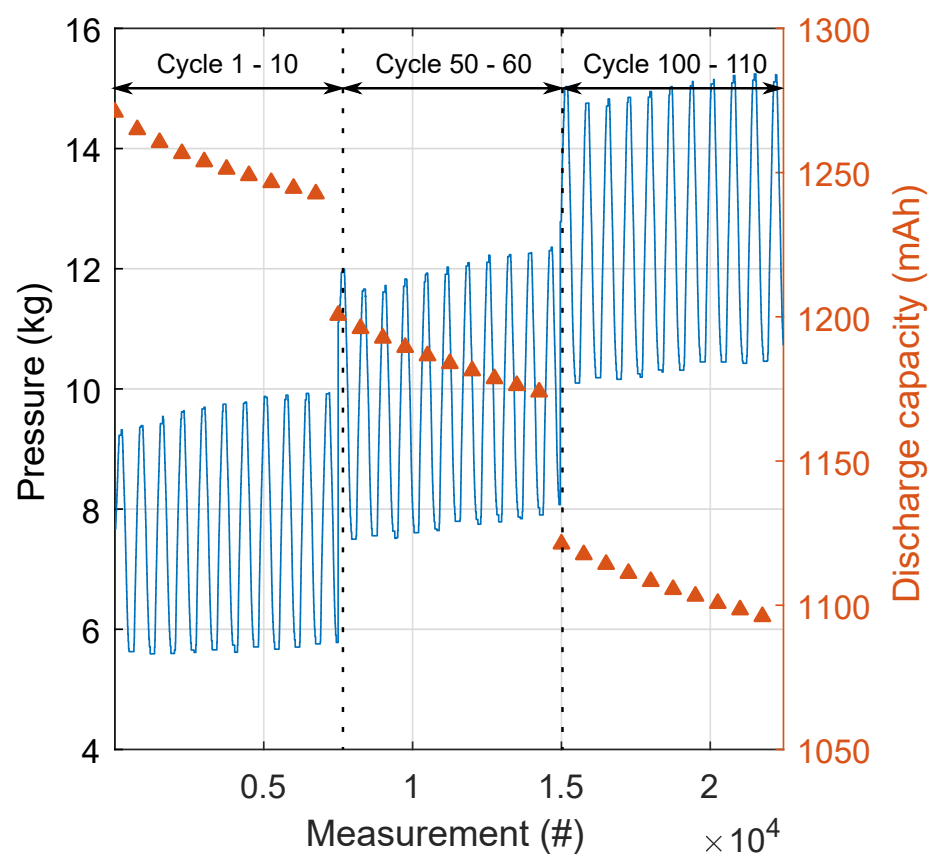

Figure 12. Measured perpendicular pressure evolution due to volumetric constraints of a Si-alloy pouch cell and the discharged capacity during cycles 1-10, 5-60 and 100-110. 


\section{Capacity Fade Modeling}

\subsection{The State of Health-Capacity Throughput Relationship}

In Section 4.2.2, we already compared the total discharged capacity throughput during cycling, for the first 150 cycles, against the capacity retention of cells cycled at different DoDs. A seemingly linear relationship could be observed in Figure $8 \mathrm{~b}$ between the capacity retention and the total discharge capacity throughput, depending on the cycling condition. To further investigate this phenomenon, the total discharged capacity throughput during cycling was calculated for all cells under the six studied cycling conditions and plotted against the SoH in Figure 13. All SoH measurements are based on the discharged capacity obtained during the QOCV check-ups at C/25 (Section 3.2), except for the $45^{\circ} \mathrm{C}$ cycling condition. Since the aging rate at this high temperature is so severe, cells reached EoL before the first check-up test. Hence, the discharged capacity for the calculation of the $\mathrm{SoH}$ for this condition was taken from the cycling test (Table 3) every 10 cycles.

From the results in Figure 13, a linear relationship between the cell's total discharge capacity throughput and its capacity retention was observed, where the slope of degradation depends on the cycling condition. To quantify this behavior, linear curve fitting was performed for every cycling condition, which relates the $\mathrm{SoH}$ to the capacity throughput $\left(\mathrm{C}_{\text {through }}\right)$ by $\mathrm{SoH}=p_{1} \times \mathrm{C}_{\text {through }}+p_{2}$. The value of coefficient $p_{2}$ (intercept) was fixed to 100 for curve fitting, as it was assumed that every cell starts cycling at $100 \%$ SoH even though it slightly reduced the goodness of fit. The linear fitting results summarized in Table 5 clearly substantiate the linearity between SoH and total discharge capacity throughput, where the degradation rate (slope) $p_{1}$ depends on the cycling condition. However, the limitation of this linearity needs to be noted: it only holds until approximately $80 \% \mathrm{SoH}$ is reached, whereafter capacity retention drops at an increased rate most likely due to depletion of cyclable lithium $[8,18,19,37]$.

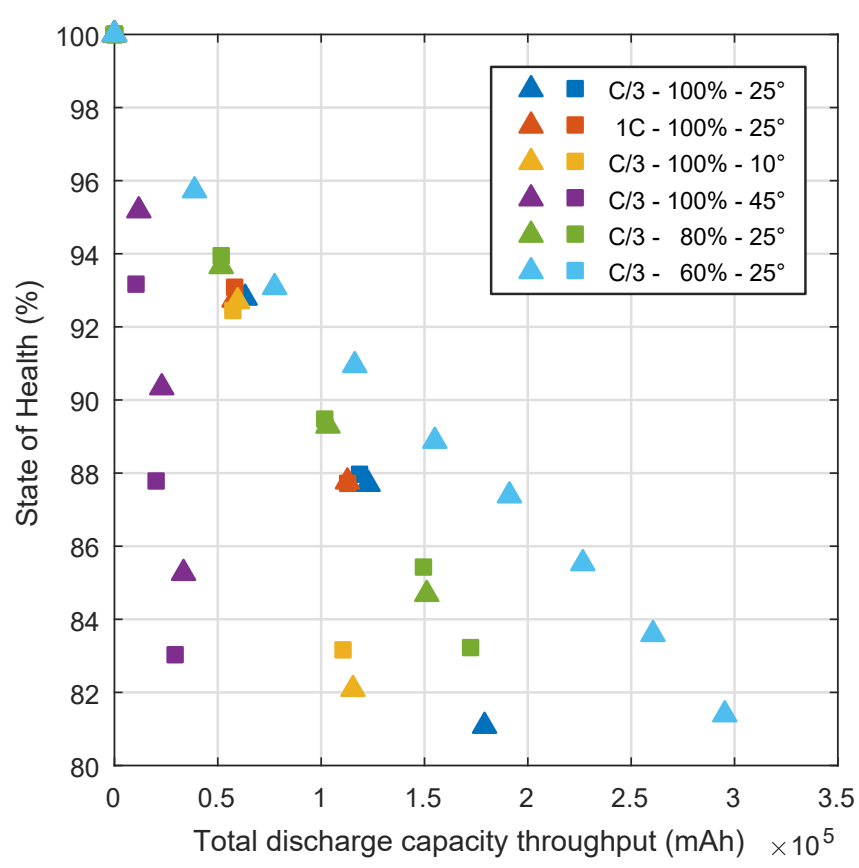

Figure 13. Linear relationship between total discharge capacity throughput (mAh) and the state of health until the EoL criterion $(80 \% \mathrm{SoH})$, for all tested Si-alloy cells under different cycling conditions. 
Table 5. Linear fitting results per cycling condition relating total discharge capacity to state of health.

\begin{tabular}{ccccccc}
\hline \multicolumn{3}{c}{ Cycling Condition } & \multicolumn{4}{c}{ Linear Fit } \\
\hline $\mathbf{T ~}\left({ }^{\circ} \mathbf{C}\right)$ & DoD (\%) & C-Rate (C) & p1 & p2 & $\mathbf{R}^{\mathbf{2}}$ & RMSE \\
\hline 25 & 100 & $1 / 3$ & $-1.048 \times 10^{-4}$ & 100 & 0.995 & 0.494 \\
25 & 100 & 1 & $-1.351 \times 10^{-4}$ & 100 & 0.953 & 2.055 \\
10 & 100 & $1 / 3$ & $-1.481 \times 10^{-4}$ & 100 & 0.987 & 0.904 \\
45 & 100 & $1 / 3$ & $-5.248 \times 10^{-4}$ & 100 & 0.958 & 1.767 \\
25 & 80 & $1 / 3$ & $-1.016 \times 10^{-4}$ & 100 & 0.993 & 0.584 \\
25 & 60 & $1 / 3$ & $-6.576 \times 10^{-5}$ & 100 & 0.963 & 1.145 \\
\hline
\end{tabular}

\subsection{Degradation Rate Equation}

The slope of capacity degradation clearly depends on the cycling condition, based on the presented results in Section 5.1. Therefore, mathematically describing the relation between the cycling stress factors Temperature (T), DoD and c-rate $(\mathrm{C})$ using a polynomial function $p_{1}(T, D o D, C)$ would allow one to estimate the capacity fade in our Si-alloy cells by simply using Equation (2), where $C_{\text {through }}$ is the measured total discharge capacity throughput. Furthermore, measuring total discharge capacity throughput is easily implementable by numerical integration of the measured current, similar to the Coulomb counting method for SoC estimation [49].

$$
\operatorname{SoH}\left(C_{\text {through }}\right)=p_{1}(T, D o D, C) \times C_{\text {through }}+p_{2}
$$

As such, the experimentally-obtained degradation rates $\left(p_{1}\right)$ shown in Table 5, together with their respective cycling condition values for $\mathrm{T}, \mathrm{DoD}$ and $\mathrm{C}$-rate are used as input for a multivariate polynomial regression analysis. The matrix representation $B=C \times A$ of the system of second order polynomial equations is presented in Equation (3), where the elements $b_{i}$ of Matrix $\mathrm{B}$ represent the experimentally-obtained degradation rates, elements $T_{i}, D o D_{i}$ and $C_{i}$ of Matrix $C$ represent the stress factors of the cycling condition and Matrix A contains the coefficients $a_{i}$ that describes their relation.

$$
\left[\begin{array}{l}
b_{1} \\
b_{2} \\
b_{3} \\
b_{4} \\
b_{5} \\
b_{6}
\end{array}\right]=\left[\begin{array}{cccccccccc}
T_{1} & D o D_{1} & C_{1} & T_{1} \cdot D o D_{1} & D o D_{1} \cdot C_{1} & T_{1} \cdot C_{1} & T_{1}^{2} & D o D_{1}^{2} & C_{1}^{2} & 1 \\
T_{2} & D o D_{2} & C_{2} & T_{2} \cdot D o D_{2} & D o D_{2} \cdot C_{2} & T_{2} \cdot C_{2} & T_{2}^{2} & D o D_{2}^{2} & C_{2}^{2} & 1 \\
\vdots & \ldots & \ldots & \ldots & \vdots & \ldots & \ldots & \ldots & \ldots & \vdots \\
T_{6} & D o D_{6} & C_{6} & T_{6} \cdot D o D_{6} & D o D_{6} \cdot C_{6} & T_{6} \cdot C_{6} & T_{6}^{2} & D o D_{6}^{2} & C_{6}^{2} & 1
\end{array}\right] *\left[\begin{array}{c}
a_{1} \\
a_{2} \\
a_{3} \\
a_{4} \\
a_{5} \\
a_{6} \\
a_{7} \\
a_{8} \\
a_{9} \\
a_{10}
\end{array}\right]
$$

This analysis results in the second order polynomial equation with three variables $p_{1}(T, D o D, C)$, presented in Equation (4). This degradation rate equation allows one to estimate the degradation rate (\%SoH/mAh) given curtain cycling conditions within the boundaries of $10{ }^{\circ} \mathrm{C}-45^{\circ} \mathrm{C}, 60-100 \% \mathrm{DoD}$ and $\mathrm{C} / 3-1 \mathrm{C}$.

$$
p_{1}(T, D o D, C)=-7.56 e^{-4} D o D+2.72 e^{-5} T-1.82 e^{-6} T \cdot C+2.07 e^{-7} T \cdot D o D-6.82 e^{-7} T^{2}+4.08 e^{-4} D o D^{2}
$$

The surface of the degradation rate equation is plotted in Figure 14a against depth of discharge and temperature at a $\mathrm{C} / 3$ current rate. The influence of current rate is not shown since only two measurement points are available $(\mathrm{C} / 3$ and $1 \mathrm{C})$, which results in a linear relation in any case. This means that the surface plot for $1 \mathrm{C}$ cycling is identical to $\mathrm{C} / 3$ cycling, only shifted downwards 
on the Z-axis due to increased capacity degradation at higher c-rates (Section 4.2.1). Furthermore, Figure 14b,c present 2D plots of respectively the DoD's and temperature's influence on the degradation rate. It is observed that the degradation rate decreases with falling $\mathrm{DoD}$, as per the results and discussion presented in Section 4.2.2. The temperature-degradation rate relationship shows a peak (lowest degradation rate) at $20{ }^{\circ} \mathrm{C}$, suggesting that this would be the optimal temperature to cycle the Si-alloy cells.
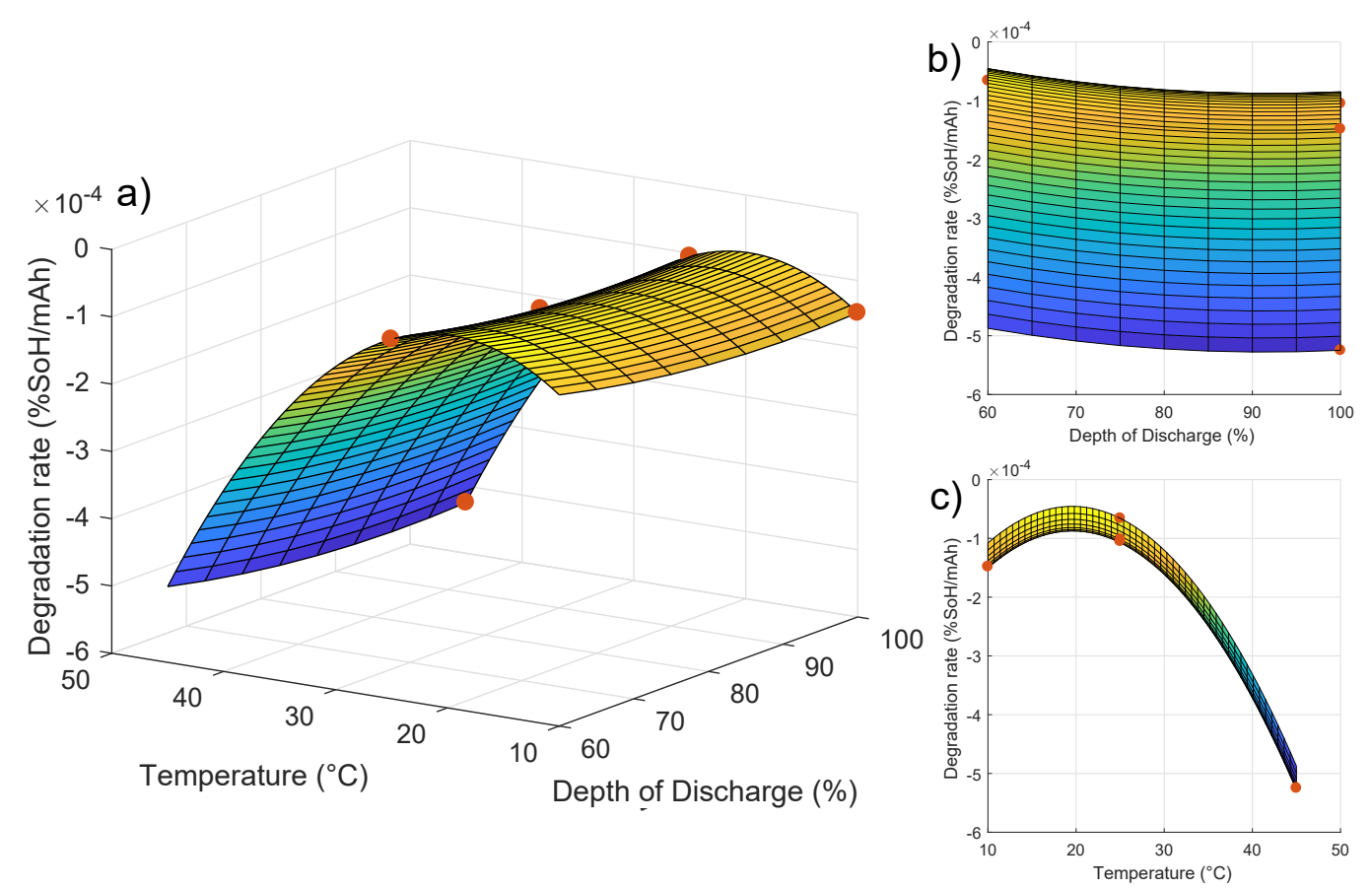

Figure 14. (a) The capacity degradation rate expressed in $\% \mathrm{SoH} / \mathrm{mAh}$ of discharged capacity throughput, mapped by the developed degradation rate Equation (4) at $\mathrm{C} / 3$ between $10{ }^{\circ} \mathrm{C}$ and $45^{\circ} \mathrm{C}$ and $60 \%$ and $100 \%$ DoD. 2D plots of the degradation rate's dependencies on (b) depth of discharge and (c) temperature, where red dots mark experimentally-observed degradation rates (Table 5).

\subsection{Dynamic Model Validation}

Next to providing an extended understanding of the Si-alloy battery aging process during more practical automotive applications (Section 4.2.4), the real-life driving cycle test condition, based on the WLTP, was also used as dynamic model validation for the developed capacity fade model. The influence of the WLTP driving cycles on the Si-alloy cell's capacity retention was previously presented in Figure 11. The model was validated by using Equation (2) with the appropriate cycling condition parameters of the WLTP for the degradation rate equation (Equation (4)), which are: $25^{\circ} \mathrm{C}$, $60 \% \mathrm{DoD}$ and $0.1430 \mathrm{C}$. It should be noted, however, that the used C-rate was the median value of the current during one WLTP discharge cycle (Section 3.3) rather than the actual current rate at every time step during cycling. This is a necessary approximation because the individual (dis-)charge events during one WLTP cycle are impossible to correlate to their respective, very limited DoD around varying middle SoCs, which goes beyond the scope of the performed cycle aging test campaign presented in Section 3.3. Nevertheless, the obtained SoH predictions using the presented capacity fade model shown in Table 6 are very promising with a median error of only $0.5 \%$ over 250 cycles, i.e., 2500 WLTP cycles. This allows us to conclude that the presented capacity fade modeling methodology is both legitimate and sufficiently accurate. 
Table 6. Dynamic validation results of the presented capacity fade model based on the WLTP driving profile.

\begin{tabular}{|c|c|c|c|c|}
\hline \multirow[t]{2}{*}{ Cycles (\#) } & \multirow[t]{2}{*}{ Capacity throughput (Ah) } & \multicolumn{3}{|c|}{ State of Health $(\%)$} \\
\hline & & Measurement & Prediction & Error \\
\hline 0 & 0.00 & 100.00 & 100.00 & 0.00 \\
\hline 50 & 49.92 & 97.05 & 97.42 & 0.36 \\
\hline 100 & 99.84 & 94.58 & 94.83 & 0.26 \\
\hline 150 & 149.77 & 92.74 & 92.25 & -0.49 \\
\hline 200 & 199.69 & 90.46 & 89.67 & -0.79 \\
\hline \multirow[t]{2}{*}{250} & 249.61 & 88.82 & 87.09 & -1.73 \\
\hline & & & $\begin{array}{c}\text { Median } \\
\text { Mean }\end{array}$ & $\begin{array}{l}-0.49 \\
-0.48\end{array}$ \\
\hline
\end{tabular}

\section{Conclusions}

In this research, twenty-four high capacity (1360 mAh) NMC622/Si-alloy Li-ion full pouch cells with high silicon content (55\%) are cycle aged under seven different cycling conditions, including the Worldwide harmonized Light Vehicles Test Procedure (WLTP) driving cycle, to study the effect of different stressors on the cycle life of Si-anode full cells, among which are the effect of ambient temperature, Depth of Discharge (DoD) and the discharge current. Since Si anodes endure substantial volumetric expansion/contraction (280-400\%) due to repeated (de-)lithiation, giving rise to high internal stresses within the anode, which lead to the consumption of cyclable lithium and capacity fade [3,5-14], the cells are volumetrically constrained to improve their cycle life. Using an innovative test setup allows us to regulate the applied initial pressure on the volumetrically-constrained Si-alloy cell during the calibration procedure, while a resistive pressure sensor allows us to measure the perpendicular counterforce as a result of repeated (de-)lithiation during cycling. After the identification of the optimal initial pressure $(7.5 \mathrm{~kg})$ during the pressure study, the uniquely vast testing campaign on Si-anode full cells allows us to study and quantify independently for the first time the influence of current rate, depth of discharge and ambient temperature on their cycle life.

Firstly, it is concluded that an increased current rate has an adverse effect on battery lifetime. The average cycles to EoL diminished from 160 to 143 for a current rate of C/3 and 1C, respectively, which corresponds to a significant decrease in battery lifetime of $10.6 \%$.

Furthermore, the results reveal a drastic improvement in cycle life for the Si-alloy cells with reduced DoD cycling conditions of up to 100 full equivalent cycles. It is concluded that the magnitude of pressure variations within the cell present the major driving force behind the cell's degradation, which are measured to be significantly less at lower DoD. Combined with the comparison of total discharge throughput during cycling against capacity retention, this supports the assumption that the induced stress of repeated (de-)lithiation of silicon particles results in continuous growth of the SEI layer on the silicon-alloy anode, during which gradual consumption of cyclable lithium occurs and the electrolyte additive FEC is depleted by parasitic reactions on the anode $[8,18,19,37]$.

Greater aging rates are observed both at $45^{\circ} \mathrm{C}$ and $10^{\circ} \mathrm{C}$ cycling conditions. Comparing capacity degradation results from calendar aging two cells at $45^{\circ} \mathrm{C}$ and $25^{\circ} \mathrm{C}$ allows us to conclude that the parasitic, electrolyte-additive-consuming reactions at the anode surface occur spontaneously and are thermally activated, which results in $\mathrm{CO}_{2}$ gas formation, increasing the internal pressure of the cell, which damages the SEI layer further and thus results in an increased consumption rate of cyclable lithium and capacity loss when cycling at higher temperatures.

It is observed that the Si-alloy cells show excellent capacity retention throughout the drive cycle aging, based on the WLTP, where one cell maintained $88.5 \%$ of its initial capacity after $46,600 \mathrm{~km}$ ( $=200$ cycles $\times 10 \mathrm{WLTP}$ 's $/$ cycle $\times 23.3 \mathrm{~km} /$ WLTP $)$. Assuming that the aging rate remains constant, linear extrapolation of the capacity retention obtains an estimate of 98,536 km to battery EoL, which allows us to conclude that Si-alloy cells show promising prospects for automotive applications. 
The pressure evolution is monitored over battery lifetime and exhibits the same behavior during all cycling conditions: as the capacity retention decreases, an irreversible pressure increase transpires. A clear relationship can be identified between capacity retention and the pressure behavior of the Si-alloy cells, which implies a correlation between the main aging mechanism within Si-alloy cells and their irreversible pressure growth. Further investigation of this phenomenon, as well as the exploration of using pressure measurements for state estimations will be the topic of a following paper.

Finally, a linear relationship between the cell's total discharge capacity throughput and its capacity retention is demonstrated, where the slope of degradation depends on the cycling condition. Therefore, the relation between the cycling condition's temperature, DoD and c-rate is described by a polynomial function that allows us to estimate the capacity fade in the Si-alloy cells by only measuring the total capacity throughput. This capacity fade model is validated using the dynamic WLTP drive cycle, showing a mean error of only $-0.5 \%$ on the predicted $\mathrm{SoH}$ after 250 cycles.

Author Contributions: Conceptualization, L.D.S. and G.B.; Methodology, L.D.S., G.B., J.S. and M.M.; Software, L.D.S.; Validation, L.D.S.; Formal analysis, L.D.S.; Investigation, L.D.S.; Resources, M.M. and M.W.-M.; Data curation, L.D.S, G.B. and J.S.; Writing, original draft preparation, L.D.S.; Writing, review and editing, Y.F., N.O. and M.M.; Visualization, L.D.S.; Supervision, J.S., J.v.M. and N.O.; Project administration, J.S., M.M. and G.B.; Funding acquisition, N.O. and M.W.-M.

Funding: This research was funded by the European Union's Horizon 2020 research and innovation program under Grant Agreement No. 653531.

Acknowledgments: We acknowledge Flanders Make for the support to our research group MOBI.

Conflicts of Interest: The authors declare no conflict of interest.

\section{Abbreviations}

The following abbreviations are used in this manuscript:

Si Silicon

SEI Solid Electrolyte Interface

WLTP Worldwide harmonized Light vehicle Test Procedure

QOCV Quasi-Open Circuit Voltage

CCCV Constant Current Constant Voltage

HPPC Hybrid Pulse Power Characterization

BoL Beginning of Life

EoL End of Life

SoC State of Charge

DoD Depth of Discharge

SoH State of Health

FEC Fluoroethylene Carbonate

\section{References}

1. NOAA National Centers for Environmental Information. State of the Climate: Global Climate Report for Annual 2017; NOAA National Centers for Environmental Information: Asheville, NC, USA, 2018.

2. Feng, K.; Li, M.; Liu, W.; Kashkooli, A.G.; Xiao, X.; Cai, M. Silicon-Based Anodes for Lithium-Ion Batteries: From Fundamentals to Practical Applications. Small 2018, 14. [CrossRef] [PubMed]

3. Louli, A.J.; Li, J.; Trussler, S.; Fell, C.R.; Dahn, J.R. Volume, Pressure and Thickness Evolution of Li-Ion Pouch Cells with Silicon-Composite Negative Electrodes. J. Electrochem. Soc. 2017. 164, 2689-2696. [CrossRef]

4. Shen, X.; Tian, Z.; Fan, R.; Shao, L.; Zhang, D.; Cao, G.; Kou, L.; Bai, Y. Research progress on silicon/carbon composite anode materials for lithium-ion battery. J. Energy Chem. 2017, 27, 1067-1090. [CrossRef]

5. Edstr, K.; Jeschull, F.; Lindgren, F.; Lacey, M.J.; Bj, F.; Brandell, D. In fluence of inactive electrode components on degradation phenomena in nano-Si electrodes for Li-ion batteries. J. Power Sour. 2016, 325, 513-524. [CrossRef] 
6. Radvanyi, E.; Havenbergh, K.V.; Porcher, W.; Jouanneau, S.; Bridel, J.s.; Put, S.; Franger, S. Study and modeling of the Solid Electrolyte Interphase behavior on nano-silicon anodes by Electrochemical Impedance Spectroscopy. Electrochim. Acta 2014, 137, 751-757. [CrossRef]

7. Steinhauer, M.; Diemant, T.; Heim, C.; Behm, R.J.; Wagner, N.; Friedrich, K.A. Solid Electrolyte Interphase Formation on Silicon and Lithium Titanate Anodes in Lithium-Ion Batteries. J. Appl. Electrochem. 2017, 47, 249-259. Available online: https: / / elib.dlr.de/111045/ (accessed on 26 July 2018).

8. Wetjen, M.; Pritzl, D.; Jung, R.; Solchenbach, S.; Ghadimi, R.; Gasteiger, H.A. Differentiating the Degradation Phenomena in Silicon-Graphite Electrodes for Lithium-Ion Batteries J. Electrochem. Soc. 2017. 164, $2840-2852$. [CrossRef]

9. Ozanam, F.; Rosso, M. Silicon as anode material for Li-ion batteries. Mater. Sci. Eng. B 2016, $213,2-11$. [CrossRef]

10. Du, Z.; Li, J.; Daniel, C.; Iii, D.L.W. Si alloy / graphite coating design as anode for Li-ion batteries with high volumetric energy density. Electrochim. Acta 2017, 254, 123-129. [CrossRef]

11. Demirkan, M.T.; Trahey, L.; Karabacak, T. Cycling performance of density modulated multilayer silicon thin film anodes in Li-ion batteries. J. Power Sour. 2015, 273, 52-61. [CrossRef]

12. Ko, M.; Chae, S.; Cho, J. Challenges in Accommodating Volume Change of Si Anodes for Li-Ion Batteries. ChemElectroChem 2015, 2, 1645-1651. [PubMed]

13. Gustafsson, T. Improved Performance of the Silicon Anode for Li-Ion Batteries: Understanding the Surface Modification Mechanism of Fluoroethylene Carbonate as an Effective Electrolyte Additive. Chem. Mater. 2015, 27, 2591-2599. [CrossRef]

14. Zuo, X.; Zhu, J.; Müller-buschbaum, P.; Cheng, Y.j. Nano Energy Silicon based lithium-ion battery anodes: A chronicle perspective review. Nano Energy 2017, 31, 113-143. [CrossRef]

15. Haruta, M.; Okubo, T.; Masuo, Y.; Yoshida, S.; Tomita, A.; Takenaka, T.; Doi, T.; Inaba, M. Temperature effects on SEI formation and cyclability of Si nano flake powder anode in the presence of SEI-forming additives. Electrochim. Acta 2017, 224, 186-193. [CrossRef]

16. Jung, R.; Metzger, M.; Haering, D.; Solchenbach, S.; Marino, C.; Tsiouvaras, N.; Stinner, C.; Gasteiger, H.A. Consumption of Fluoroethylene Carbonate (FEC) on Si-C Composite Electrodes for Li-Ion Batteries. J. Electrochem. Soc. 2016, 166. [CrossRef]

17. Leung, K.; Rempe, S.B.; Foster, M.E.; Ma, Y. Modeling Electrochemical Decomposition of Fluoroethylene Carbonate on Silicon Anode Surfaces in Lithium Ion Batteries. J. Electrochem. Soc. 2014, 161, $213-221$. [CrossRef]

18. Dupre, N.; Moreau, P.; Vito, E.D.; Quazuguel, L.; Boniface, M.; Bordes, A.; Rudisch, C.; Guyomard, D. Multiprobe Study of the Solid Electrolyte Interphase on Silicon-Based Electrodes in Full-Cell Configuration. Chem. Mater. 2016, 28, 2557-2572. [CrossRef] [PubMed]

19. Delpuech, N.; Dupre, N.; Moreau, P.; Bridel, J.S. Mechanism of Silicon Electrode Aging upon Cycling in Full Lithium-Ion Batteries. ChemElectroChem 2016, 9, 841-848. [CrossRef] [PubMed]

20. Chevrier, V.L.; Liu, L.; Wohl, R.; Chandrasoma, A.; Vega, J.A.; Eberman, K.W.; Stegmaier, P.; Figgemeier, E.; Hampshire, N. Design and Testing of Prelithiated Full Cells with High Silicon Content. J. Electrochem. Soc. 2018, 165, 1129-1136. [CrossRef]

21. Berckmans, G.; De Sutter, L.; Kersys, A.; Kriston, A.; Marinaro, M.; Kasper ,M.; Axmann, P.; Smekens, J.; Wohlfahrt-Mehrens, M.; Pfrang, A.; et al. Electrical Characterization and Micro X-ray Computed Tomography Analysis of Next-Generation Silicon Alloy Cells. World Electr. Veh. J. 2018, 9, 43. [CrossRef]

22. Kierzek, K.; Machnikowski, J. Factors influencing cycle-life of full Li-ion cell built from Si/C composite as anode and conventional cathodic material. Electrochim. Acta 2016, 192, 475-481. [CrossRef]

23. Lu, W.; Zhang, L.; Qin, Y.; Jansen, A. Calendar and Cycle Life of Lithium-Ion Batteries Containing Silicon Monoxide Anode J. Electrochem. Soc. 2018, 165, 2179-2183. [CrossRef]

24. Kalaga, K.; Rodrigues, M.t.F.; Trask, S.E.; Shkrob, I.A.; Abraham, P. Calendar-life versus cycle-life aging of lithium-ion cells with silicon-graphite composite electrodes. Electrochim. Acta 2018, 280, 221-228. [CrossRef]

25. Klett, M.; Gilbert, J.A.; Trask, S.E.; Polzin, B.J.; Jansen, A.N.; Dees, D.W.; Abraham, D.P. Electrode Behavior RE-Visited: Monitoring Potential Windows , Capacity Loss , and Impedance Changes in $\mathrm{Li}_{1.03}$ $\left(\mathrm{Ni}_{0.5} \mathrm{Co}_{0.2} \mathrm{Mn}_{0.3}\right) 0.97 \mathrm{O}_{2}$ /Silicon-Graphite Full Cells J. Electrochem. Soc. 2016, 163, 875-887. [CrossRef] 
26. Marinaro, M.; Yoon, D.H.; Gabrielli, G.; Stegmaier, P.; Schmidt, G.; Chauveau, J.; Figgemeier, E.; Spurk, P.C.; Axmann, P.; Wohlfahrt-mehrens, M. High performance 1.2 Ah Si-alloy/GraphitejLiNi ${ }_{0.5} \mathrm{Mn}_{0.3} \mathrm{Co}_{0.2} \mathrm{O}_{2}$ prototype Li-ion battery. J. Power Sour. 2017, 357, 188-197. [CrossRef]

27. Gabrielli, G.; Marinaro, M.; Mancini, M.; Axmann, P.; Wohlfahrt-mehrens, M. A new approach for compensating the irreversible capacity loss of high- A new approach for compensating the irreversible capacity loss of high-energy $\mathrm{Si} / \mathrm{C} \mathrm{j} \mathrm{LiNi}{ }_{0.5} \mathrm{Mn}_{1.5} \mathrm{O}_{4}$ lithium-ion batteries. J. Power Sour. 2017, 351, $35-44$. [CrossRef]

28. Electrically Propelled Road Vehicles-Test Specification for Lithium-Ion Traction Battery Packs and Systems-Part 1: High-Power Applications. ISO 12405-2. Available online: https://www.iso.org/standard/ 55854.html (accessed on 15 July 2018).

29. Electrically Propelled Road Vehicles-Test Specification for Lithium-Ion Traction Battery Packs and Systems-Part 2: High Energy Application. ISO 12405-1. Available online: https:/ /www.iso.org/standard/ 51414.html (accessed on 15 July 2018).

30. Secondary Lithium-Ion Cells for the Propulsion of Electric Road Vehicles-Part 1: Performance Testing. IEC 62660-1. Available online: https:/ / webstore.iec.ch/publication/7331 (accessed on 15 July 2018).

31. Secondary Batteries for the Propulsion of Electric Road Vehicles-Part 2: Dynamic Discharge Performance Test and Dynamic Endurance Test. IEC 61982-2. Available online: https:/ /webstore.iec.ch/publication/ 20204 (accessed on 15 July 2018).

32. Hoog, J.D.; Timmermans, J.M.; Ioan-Stroe, D.; Swierczynski, M.; Jaguemont, J.; Goutam, S.; Omar, N.; Mierlo, J.V.; Bossche, P.V.D. Combined cycling and calendar capacity fade modeling of a Nickel-Manganese-Cobalt Oxide Cell with real-life profile validation. Appl. Energy 2017, 200, 47-61. [CrossRef]

33. Waldmann, T.; Wilka, M.; Kasper, M.; Fleischhammer, M.; Wohlfahrt-mehrens, M. Temperature dependent ageing mechanisms in Lithium-ion batteries e A Post-Mortem study. J. Power Sour. 2014, 262, 129-135. [CrossRef]

34. Jalkanen, K.; Karppinen, J.; Skogström, L.; Laurila, T.; Nisula, M.; Vuorilehto, K. Cycle aging of commercial NMC/graphite pouch cells at different temperatures. Appl. Energy 2015, 154, 160-172. [CrossRef]

35. Wang, J.; Liu, P.; Hicks-garner, J.; Sherman, E.; Soukiazian, S.; Verbrugge, M.; Tataria, H.; Musser, J.; Finamore, P. Cycle-life model for graphite-LiFePO 4 cells. J. Power Sour. 2011, 196, 3942-3948. [CrossRef]

36. Omar, N.; Abdel, M.; Firouz, Y.; Salminen, J.; Smekens, J.; Hegazy, O.; Gaulous, H.; Mulder, G.; Bossche, P.V.D.; Coosemans, T. Lithium iron phosphate based battery-Assessment of the aging parameters and development of cycle life model. Appl. Energy 2014, 113, 1575-1585. [CrossRef]

37. Klett, M.; Gilbert, J.A.; Pupek, K.Z.; Trask, S.E.; Abraham, D.P. Layered Oxide, Graphite and Silicon-Graphite Electrodes for Lithium-Ion Cells: Effect of Electrolyte Composition and Cycling Windows. J. Electrochem. Soc. 2017, 164, 6095-6102. [CrossRef]

38. Deshpande, R.; Verbrugge, M.; Cheng, Y.t.; Wang, J.; Liu, P. Battery Cycle Life Prediction with Coupled Chemical Degradation and Fatigue Mechanics. J. Electrochem. Soc. 2012, 159, 1730-1738. [CrossRef]

39. Sun, S.; Guan, T.; Shen, B.; Leng, K.; Gao, Y.; Cheng, X. Changes of Degradation Mechanisms of $\mathrm{LiFePO}_{4} /$ Graphite Batteries Cycled at Different Ambient Temperatures. Electrochim. Acta 2017, 237, 248-258. [CrossRef]

40. Leng, F.; Tan, C.M.; Pecht, M. Effect of Temperature on the Aging rate of Li Ion Battery Operating above Room Temperature. Sci. Rep. 2015, 1-12. [CrossRef] [PubMed]

41. Jin, Y.; Zhu, B.; Lu, Z.; Liu, N.; Zhu, J. Challenges and Recent Progress in the Development of Si Anodes for Lithium-Ion Battery. Adv. Energy Mater. 2017, 7, 1-17. [CrossRef]

42. Sethuraman, V.A.; Winkle, N.V.; Abraham, D.P.; Bower, A.F.; Guduru, P.R. Real-time stress measurements in lithium-ion battery negative-electrodes. J. Power Sour. 2012, 206, 334-342. [CrossRef]

43. Bucci, G.; Swamy, T.; Bishop, S.; Sheldon, B.W.; Chiang, Y.m.; Carter, W.C. The Effect of Stress on Battery-Electrode Capacity. J. Electrochem. Soc. 2017, 166. [CrossRef]

44. Cheng, X.; Pecht, M. In Situ Stress Measurement Techniques on Li-ion Battery Electrodes: A Review. Energies 2017, 10, 591. [CrossRef]

45. Glazier, S.L.; Li, J.; Louli, A.J.; Allen, J.P.; Dahn, J.R. An Analysis of Artificial and Natural Graphite in Lithium Ion Pouch Cells Using Ultra-High Precision Coulometry, Isothermal Microcalorimetry, Gas Evolution, Long Term Cycling and Pressure Measurements. J. Electrochem. Soc. 2017, 164, 3545-3555. [CrossRef] 
46. Cannarella, J.; Arnold, C.B. State of health and charge measurements in lithium-ion batteries using mechanical stress. J. Power Sour. 2014, 269, 7-14. [CrossRef]

47. Dai, H.; Yu, C.; Wei, X.; Sun, Z. State of charge estimation for lithium-ion pouch batteries based on stress measurement. Energy 2017, 129, 16-27. [CrossRef]

48. Cui, Y.; Du, C.; Yin, G.; Gao, Y.; Zhang, L.; Guan, T. Multi-Stress Factor Model for Cycle Lifetime Prediction of Lithium Ion Batteries with Shallow-Depth Discharge. J. Power Sour. 2015. [CrossRef]

49. Hannan, M.A.; Lipu, M.S.H.; Hussain, A.; Mohamed, A. A review of lithium-ion battery state of charge estimation and management system in electric vehicle applications: Challenges and recommendations. Renew. Sustain. Energy Rev. 2017, 78, 834-854. [CrossRef]

(C) 2018 by the authors. Licensee MDPI, Basel, Switzerland. This article is an open access article distributed under the terms and conditions of the Creative Commons Attribution (CC BY) license (http://creativecommons.org/licenses/by/4.0/). 